\title{
Pengembangan Media Pembelajaran Biologi Berbasis Android Menggunakan Model Pembelajaran Problem Based Learning Pada Materi Sistem Ekskresi Di Kelas VIII SMP
}

\author{
Theresia Nona Elci ${ }^{1,{ }^{*}}$, Yohanes Bare ${ }^{1)}$, Oktavius Yoseph Tuta Mago ${ }^{1)}$ \\ ${ }^{1)}$ Pendidikan Biologi, FKIP, Universitas Nusa Nipa Indonesia \\ *nonaelcy@gmail.com
}

Abstrak: Pandemi covid-19 berdampak pada berbagai bidang kehidupan manusia salah satunya bidang pendidikan, mengakibatkan pembelajaran di sekolah harus dilakukan secara online. Penelitian ini bertujuan untuk mengembangkan media pembelajaran biologi berbasis android menggunakan model pembelajaran problem based learning pada materi sistem ekskresi di kelas VIII SMP. Metode yang digunakan dalam penelitian pengembangan ini mengacu pada prosedural model Borg \& Gall yang menggunakan delapan dari sepuluh tahap tanpa mengurangi nilai dari penelitian dan pengembangan tersebut. Berdasarkan beberapa tahapan uji coba yang dilakukan para ahli : ahli materi $(89,15)$, ahli bahasa $(90)$, ahli media $(87,13)$. Keseluruhan nilai rata-rata untuk validasi ahli memperoleh kriteria sangat valid. Uji kelayakan media oleh pendidik dan peserta didik : uji lapangan terbatas oleh pendidik (79) dan peserta didik $(60,5)$. Uji lapangan lebih luas oleh pendidik $(79,5)$ dan peserta didik $(66,92)$. Uji kelayakan oleh pendidik (86) dan peserta didik $(70,50)$. Keseluruhan nilai rata-rata pendidik dan peserta didik memperoleh kriteria kelayakan sangat layak. Penelitian ini memberikan manfaat positif bagi dunia pendidikan terutama di masa pandemi covid-19 yaitu memudahkan peserta didik untuk mendapatkan materi bahan ajar, meningkatkan kemampuan belajar mandiri peserta didik, aplikasi tersebut mudah digunakan dan bisa di bawa kemanapun.

Kata Kunci: efektivitas, kelayakan, media android, pengembangan, validasi

\section{Pendahuluan}

Pandemi covid-19 berdampak pada berbagai bidang kehidupan manusia, salah satunya bidang pendidikan yang mengakibatkan pembelajaran di sekolah harus dilakukan secara online. Salah satu platform dalam pembelajaran online adalah pemanfaatan media berbasis android. Penerapan media android merupakan salah satu pemanfaatan teknologi yang bersifat praktis dalam kegiatan pembelajaran yang sesuai dengan karakteristik revolusi industri 4.0 (Suryaningsih dkk., 2020).

Hasil observasi di SMP Muhammadiyah Waipare selama PPL menunjukkan bahwa proses pembelajaran biologi belum pernah menggunakan media pembelajaran berbasis android. Proses pembelajaran masih menggunakan LKPD sebagai media pembelajaran. Hal tersebut membuat peserta didik merasa bosan dan jenuh sehingga minat belajar peserta didik menurun. Berkaitan dengan hal tersebut, peneliti memberikan sebuah solusi yang bermanfaat melalui pengembangan media pembelajaran biologi berbasis android.

Salah satu kelebihan mendasar menggunakan media pembelajaran biologi berbasis android ini yaitu pembelajaran tidak hanya dapat diperoleh dari sekolah, tetapi juga dapat dilakukan kapan saja dan dimana saja. Selain itu, terdapat beberapa kelebihan lain diantaranya media pembelajaran ini sangat mudah dioperasikan, memiliki desain yang menarik, materi yang disajikan sederhana namun mudah dipahami, terdapat soal-soal latihan yang sesuai dengan KD dan indikator, tidak bergantung dengan adanya jaringan data karena dapat digunakan secara offline. Hasil penelitian Kuswanto (2019) menyatakan bahwa media pembelajaran berbasis android yang di kembangkan layak diterapkan dalam pembelajaran Biologi di kelas XI. Penelitian Jano (2019) menjelaskan bahwa media pembelajaran berbasis android yang dikembangkan dinilai sesuai dan layak digunakan untuk pembelajaran kimia pada peningkatan performa akademik peserta didik di SMA. 
Pemanfaatan media pembelajaran android ini diintegrasikan dengan model pembelajaran Problem Based Learning (PBL). PBL merupakan sebuah model pembelajaran dimana keseluruhan proses diorientasikan untuk membantu siswa menjadi mandiri, otonom, percaya pada keterampilan intelektual sendiri melalui keterlibatan aktif dan bebas mengemukakan pendapat. PBL memiliki pengaruh dalam meningkatkan kemampuan berpikir kritis peserta didik (Dewi dan Utami, 2016). Sistem ekskresi merupakan salah satu materi pelajaran yang dikaji sulit dalam memahami materi yang berhubungan dengan organ internal (Nuroifah dan Bachri, 2015). Kesulitan dalam proses belajar yang menuntut peserta didik untuk menghafal terminologi maupun bahasa Latin pada pengenalan organ yang terlibat dalam proses pengeluaran manusia, sulit membedakan proses pengeluaran pada manusia, serta pemahaman tentang proses pembentukan urin yang sulit dimengerti (Simorangkir dan Napitupulu, 2020). Materi ini membutuhkan pemahaman yang kuat sehingga dibutuhkan media pembelajaran untuk membantu peserta didik. Tujuan penelitian ini adalah untuk mengembangkan media Pembelajaran Biologi Berbasis Android Menggunakan Model Pembelajaran Problem Based Learning Pada Materi Sistem Ekskresi di Kelas VIII SMP.

\section{Metode}

\section{Waktu Penelitian dan Tempat Penelitian}

Penelitian ini akan dilaksanakan pada tanggal 21 April - 31 Mei 2021/ semester genap tahun pelajaran 2020/2021. Tempat Penelitian di SMP Muhammadiyah Waipare, Jl. Nairoa, Desa Watumilok, Kec. Kangae, Kabupaten Sikka.

\section{Model Penelitian}

Penelitian ini dilakukan dengan menggunakan jenis penelitian dan pengembangan (Research and Development) dengan mengadopsi model pengembangan dari Borg \& Gall. Menurut Borg \& Gall (2003). Subjek penelitian ini yaitu peserta didik kelas VIII. Uji lapangan terbatas sebanyak 10 peserta didik dan 1 orang pendidik mata pelajaran biologi. Uji lapangan lebih luas sebanyak 40 orang peserta didik dan 2 orang pendidik mata pelajaran biologi. Uji kelayakan terdiri dari 2 sekolah yaitu SMP Muhammadiyah Waipare yang terdiri dari 50 orang peserta didik serta 2 orang pendidik dan SMPN 1 Kewapante terdiri dari 11 peserta didik dan 1 orang pendidik. Jenis Data berupa Angket atau kuisioner, Dokumentasi.

\section{Teknik Analisis Data}

Data yang diperoleh melalui instrumen penelitian selanjutnya diolah dan di analisis dengan maksud agar hasilnya dapat menjawab pertanyaan penelitian.

\section{Data Analisis Validitas}

Data analisis validitas diperoleh dari data hasil penelitian yang dilakukan oleh ahli media, ahli materi dan ahli bahasa. Data analisis validitas produk diolah dengan menggunakan persentase validitas (Tabel 1). Penilaian untuk validitas dilakukan dengan menggunakan skala Likert berupa data kuantitatif (Permatasari dan Wakhyudin, 2017).

Tabel 1. Kriteria Validitas

\begin{tabular}{ccc}
\hline No & Kriteria Validitas & Tingkat Validitas \\
\hline 1 & $81,00 \%-100,00 \%$ & Sangat Valid \\
2 & $61,00 \%-80,00 \%$ & Valid \\
3 & $41,00 \%-60,00 \%$ & Kurang Valid \\
4 & $21,00 \%-40,00 \%$ & Tidak Valid \\
5 & $00,00 \%-20,00 \%$ & Sangat Tidak Valid \\
\hline \multicolumn{3}{c}{ (Permatasari dan Wakhyudin, 2017) }
\end{tabular}

\section{Data Analisis Kelayakan}

Data analisis kelayakan berupa data kualitatif yang diperoleh pada saat uji coba produk berupa angket yang di buat menggunakan skala Likert (Adi, 2016), data selanjutnya diubah menggunakan nilai kategori klasifikasi nilai kategori (Adi, 2016). Data hasil angket tentang penilaian kelayakan media pembelajaran biologi 
berbasis android dari pendidik pada uji coba skala kecil, skala menengah dan uji coba skala besar kemudian di olah menjadi kategori penilaian kelayakan media. Kategori produk hasil penilaian kelayakan media oleh pendidik (Tabel 2).

Tabel 2. Kategori Hasil Penilaian Produk Kelayakan Media oleh Pendidik

\begin{tabular}{ccc}
\hline No & Rentang Skor & Kategori \\
\hline 1 & $\mathrm{X}>79,68$ & Sangat Layak \\
2 & $64,56<\mathrm{X} \leq 79,68$ & Layak \\
3 & $49,44<\mathrm{X} \leq 64,56$ & Cukup Layak \\
4 & $34,32<\mathrm{X} \leq 49,44$ & Kurang Layak \\
5 & $\mathrm{X} \leq 34,32$ & Sangat Kurang Layak \\
\hline
\end{tabular}

Angket peserta didik di analisis dan di olah menjadi kategori penilaian kelayakan media. Kategori produk hasil penilaian kelayakan media oleh peserta didik (Tabel 3.).

Tabel 3. Kategori Hasil Penilaian Produk Kelayakan Media oleh Peserta Didik

\begin{tabular}{ccc}
\hline No & Rentang Skor & Kategori \\
\hline 1 & $\mathrm{X}>63$ & Sangat Layak \\
2 & $51<\mathrm{X} \leq 63$ & Layak \\
3 & $39<\mathrm{X} \leq 51$ & Cukup Layak \\
4 & $27<\mathrm{X} \leq 39$ & Kurang Layak \\
5 & $\mathrm{X} \leq 27$ & Sangat Kurang Layak \\
\hline
\end{tabular}

\section{Hasil dan Pembahasan}

Penelitian dan pengembangan yang dilakukan mengacu pada model Borg \& Gall. Penelitian ini hanya menggunakan delapan tahap dari sepuluh tahap, namun tanpa mengurangi nilai dari penelitian dan pengembangan tersebut. Penyederhanaan tersebut untuk melihat kelayakan dari media yang dikembangkan.

\section{Studi Pendahuluan}

Pada tahap studi pendahuluan yakni studi lapangan. Studi lapangan yakni datang secara langsung ke SMP Muhammadiyah Waipare untuk melakukan pra-penelitian, ditemukan beberapa permasalahan dalam pembelajaran biologi khususnya materi sistem ekskresi seperti peserta didik yang sulit membedakan proses pengeluaran pada manusia, sulit menghafal terminologi maupun bahasa latin pada pengenalan organ yang terlibat dalam proses pengeluaran manusia. Selain itu, guru lebih banyak menggunakan LKPD dan buku cetak sehingga peserta didik merasa bosan.

\section{Perencanaan Penelitian}

Hasil perencanaan penelitian yakni materi sistem ekskresi yang sesuai dengan KD dan Indikator, soal-soal pre-test dan post-test untuk menguji efektivitas. Instrumen penilaian berupa angket dan lembar validasi yang disesuaikan dengan masing-masing kategori ahli yang menilai, yaitu ahli kemediaan, ahli kematerian, ahli kebahasaan, guru biologi, dan peserta didik kelas VIII.

\section{Pengembangan Produk Awal}

Pengembangan produk awal mencakup proses pembuatan media pembelajaran biologi berbasis android.

\section{Halaman awal}

Halaman awal merupakan halaman depan aplikasi ketika login ke aplikasi. Halaman ini terdiri atas nama materi serta menu start yang berfungsi untuk menggerakan halaman ke halaman menu (Gambar 1).

\section{Halaman menu}

Halaman menu berisi menu yang berfungsi untuk menggerakan halaman ke halaman yang ditujukan. Menu yang tersedia pada halaman menu meliputi menu petunjuk, menu kompetensi, menu materi, menu profil dan menu audio (Gambar 2). 
Menu Petunjuk

Menu petunjuk memiliki 1 halaman, yakni halaman petunjuk yang berisi petunjuk penggunaan tomboltombol yang terdapat pada setiap halaman. Pada halaman petunjuk terdapat tombol home yang akan mengembalikan halaman petunjuk ke halaman menu (Gambar 3).

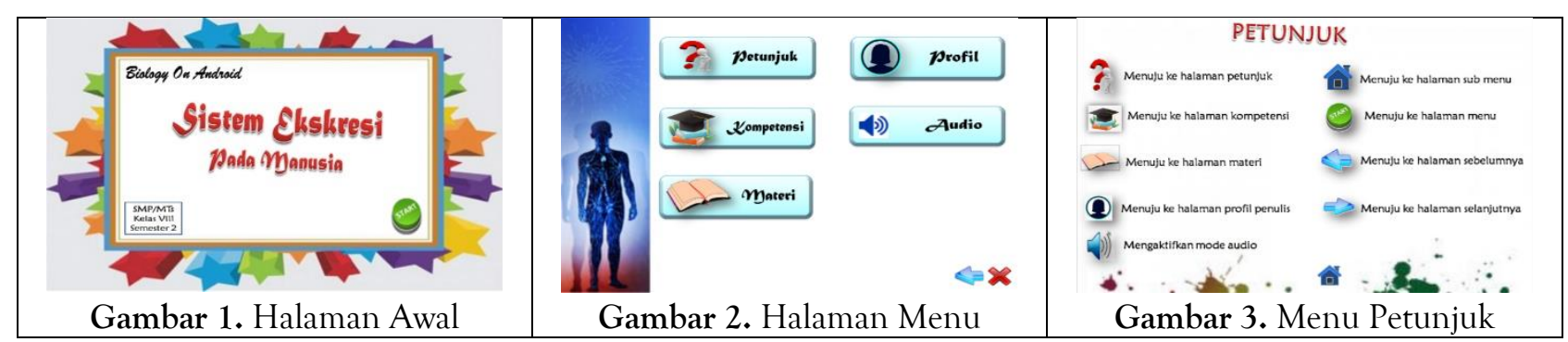

Menu Kompetensi

Menu kompetensi memiliki 3 halaman, yakni halaman pertama yang berisi menu untuk kompetensi dasar, IPK, dan tujuan pembelajaran. Halaman kedua berisi KD dan IPK, halaman ketiga berisi tujuan pembelajaran. Halaman kompetensi dasar menggambarkan susunan kerangka kompetensi suatu kurikulum. IPK diturunkan dari kompetensi dasar yang harus dicapai peserta didik dalam kegiatan pembelajaran. Tujuan pembelajaran diturunkan dari indikator pencapaian kompetensi agar peserta didik mempunyai tujuan pembelajaran yang jelas sesuai materi yang dipelajari.

Menu Materi

Materi sistem ekskresi yang ada pada media android disajikan berdasarkan model pembelajaran PBL. Halaman materi diawali dengan mengorientasikan peserta didik terhadap masalah (Gambar 4.).

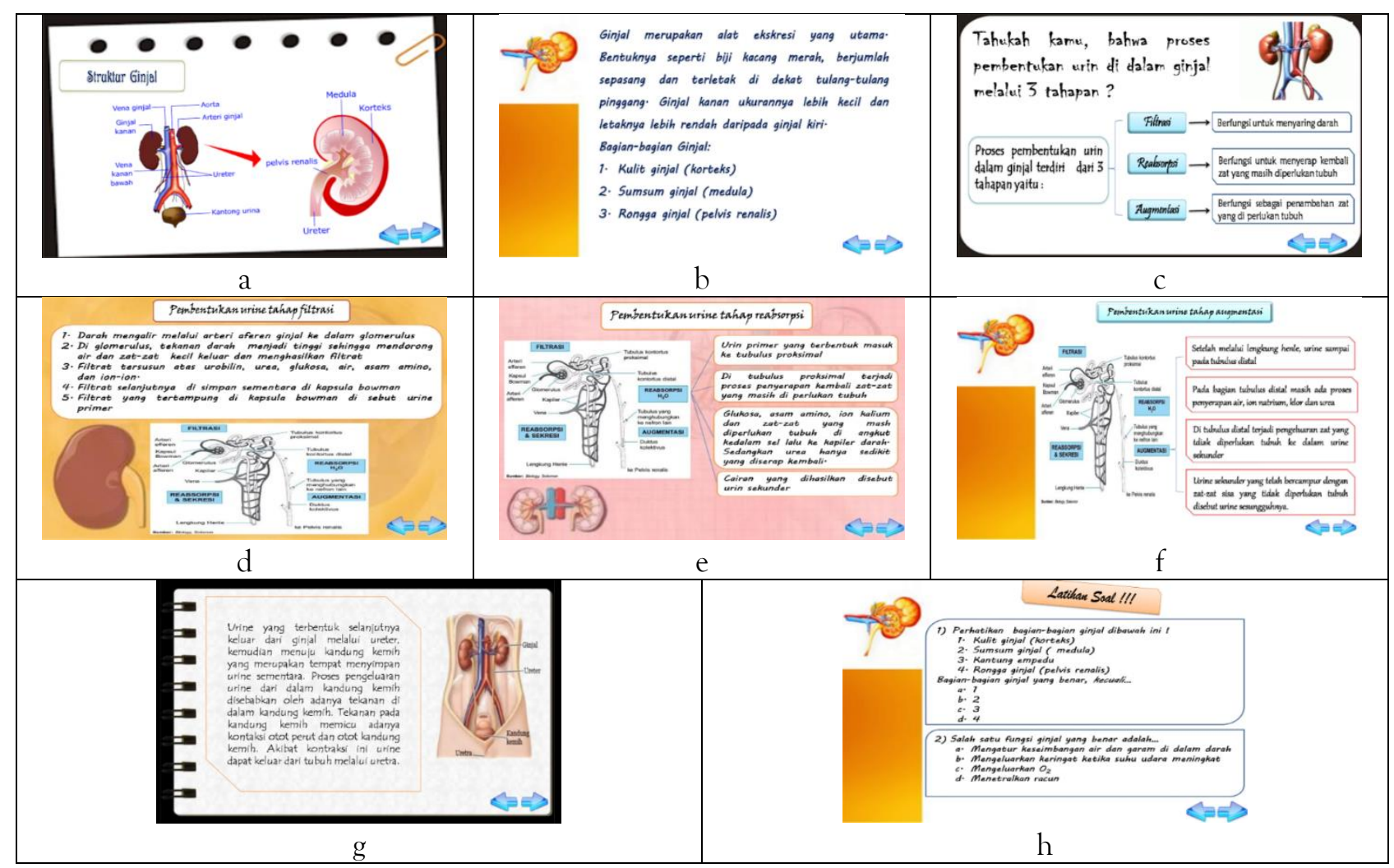

Gambar 4. Tampilan awal materi

Setelah media selesai dibuat kemudian dilakukan validasi. Uji validasi diberikan kepada validator materi, validator bahasa dan validator media yang masing-masing terdiri dari dua orang. 
Validator Materi

Validator materi melakukan validasi terhadap isi atau konten materi pada media pembelajaran yang dikembangkan. Validasi yang dilakukan oleh validator materi mendapat beberapa saran perbaikan yakni pada materi ginjal sebaiknya fungsi ginjal dengan proses pembentukan urin disatukan dalam satu slide karena merupakan satu kesatuan. Pada materi paru-paru terdapat pendobelan penjelasan terkait fungsi paru-paru sebagai organ ekskresi. Pada slide awal sebaiknya dirangkum secara keseluruhan terkait sistem ekskresi.

Validator media

Validator media melakukan validasi terhadap media pembelajaran yang dikembangkan. Jumlah indikator sebanyak 14 yang meliputi aspek antarmuka (interface), informasi bantuan, navigasi, dan robustness.

\section{Validator Bahasa}

Validator bahasa melakukan validasi terhadap tata bahasa dan tulisan pada media pembelajaran yang dikembangkan dengan jumlah 10 indikator aspek antarmuka (interface).

Penelitian Chairunnisa (2019) tentang pengembangan mobile learning berbasis android pada konsep sistem sirkulasi menyatakan bahwa penilaian oleh ahli media sangat valid Penelitian yang dilakukan oleh Setyantoko (2016) menyatakan bahwa kelayakan telah teruji dengan baik dari segi materi, media maupun dari faktor usability dengan kategori "sangat layak" pada masing-masing tahap pengujian. Nilai validasi dari para validator akan memberikan nilai kevalidan media yang dikembangkan (Bare \& Sari, 2021; Sizi et al., 2021; Ule et al., 2021).

Tabel 4. Data Hasil Validasi oleh Validator

\begin{tabular}{ccccc}
\hline No & Validator & Data Hasil Validasi (\%) & Rata-rata & Tingkat Validitas \\
\hline 1 & Materi (1) & $90 \%$ & 89,15 & Sangat Valid \\
2 & Materi (2) & $88,3 \%$ & & \\
3 & Bahasa (1) & $100 \%$ & 90 & Sangat Valid \\
4 & Bahasa (2) & $80 \%$ & & \\
5 & Media (1) & $91,42 \%$ & 87,135 & Sangat Valid \\
6 & Media (2) & $82,85 \%$ & & \\
\hline
\end{tabular}

Lembar validasi media pembelajaran biologi berbasis android pada materi sistem ekskresi kelas VIII SMP. Media pembelajaran biologi berbasis android setelah divalidasi oleh validator, produk tersebut kemudian direvisi berdasarkan hasil analisis, saran dan masukan dari validator. Produk dari hasil revisi digunakan untuk tahap selanjutnya, yakni tahap uji lapangan terbatas (Tabel 6).

\section{Uji Lapangan Terbatas}

Produk media pembelajaran biologi berbasis android pada materi sistem ekskresi di kelas VIII SMP yang sudah divalidasi dan direvisi kemudian diujicobakan pada uji lapangan terbatas. Saran dan tanggapan yang diberikan oleh peserta didik yaitu perbaikan pada materi paru-paru untuk proses pertukaran gas di dalam alveolus ukuran huruf terlalu kecil.

Teknik analisis data kelayakan media yang diolah berdasarkan skala Likert dan rumus kategori produk.

\section{Hasil Analisis Data Uji Lapangan Terbatas}

Hasil uji coba produk terhadap pendidik dan peserta didik digunakan untuk menentukan kelayakan media. Hasil analisis data yang diperoleh untuk peserta didik yaitu 60,5 dikategorikan layak, sedangkan untuk pendidik yaitu 79 dan dikategorikan layak (Tabel 5).

Tabel 5. Penilaian Kelayakan oleh Pendidik dan Peserta didik

\begin{tabular}{clcccc}
\hline No & Kelayakan Media & Pendidik & Kategori & Peserta Didik & Kategori \\
\hline 1 & Uji Lapangan Terbata & 60,5 & Layak & 79 & Layak \\
\hline 2 & Uji Lapangan Luas & 66,925 & Sangat Layak & 79,5 & Layak \\
\hline 3 & Uji Kelayajan & 70,5 & Sangat Layak & 86 & Sangat Layak \\
\hline
\end{tabular}


Tabel 6. Media Pembelajaran Sebelum Revisi dan Sesudah Revisi

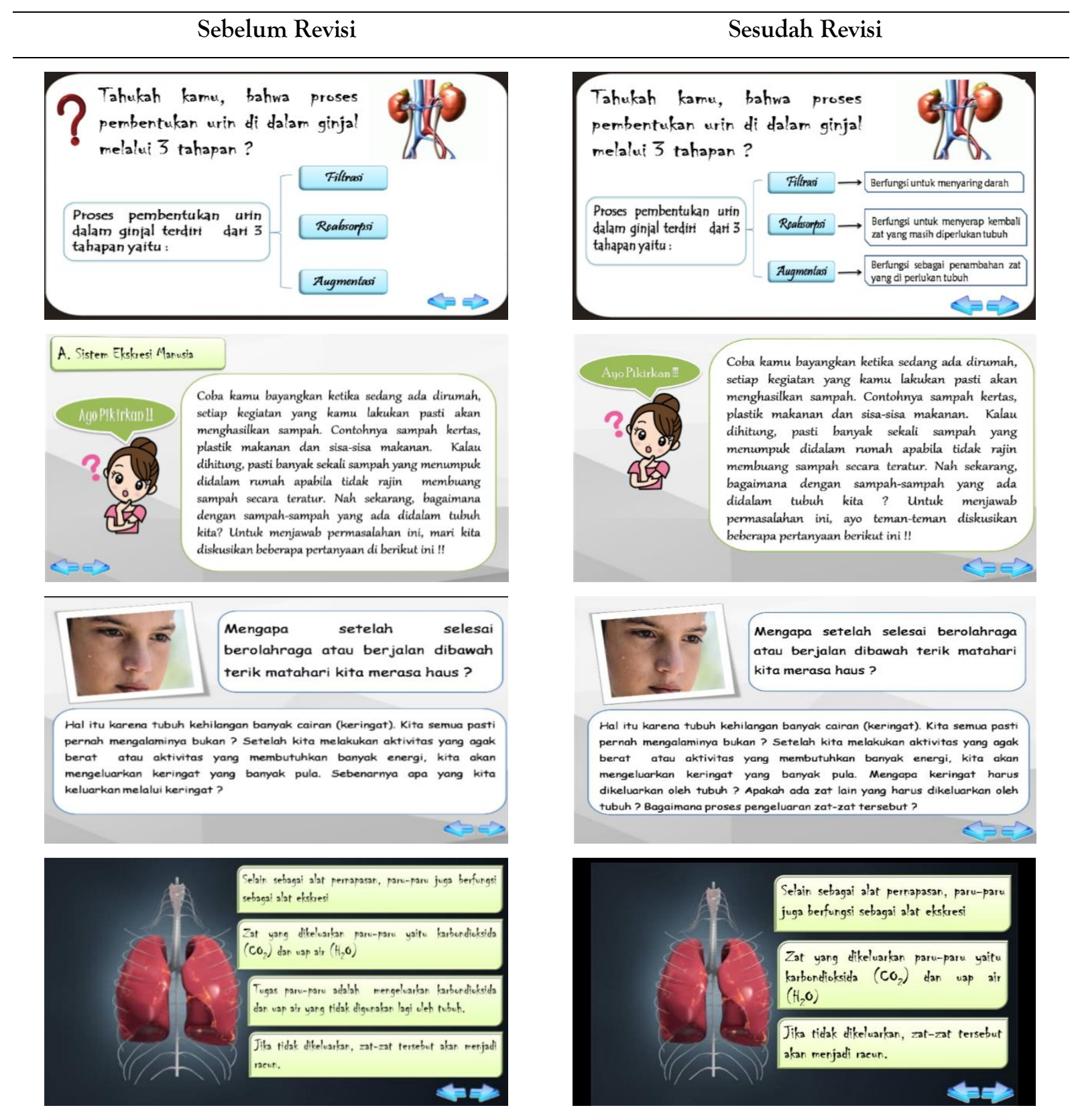

Hasil Analisis Data Uji Lapangan Lebih Luas

Pada uji lapangan lebih luas, media dinilai oleh 40 orang peserta didik kelas VIII dan 2 orang pendidik mata pelajaran biologi, dengan menggunakan angket penilaian media. Hasil analisis data uji lapangan lebih luas diperoleh rerata skor untuk peserta didik sebesar 66,925 dan dikategorikan sangat layak, sedangkan rerata skor penilaian media oleh pendidik sebesar 79,5 dan dikategorikan layak (Tabel 6).

Hasil Analisis Data Uji Kelayakan

Rerata skor untuk peserta didik adalah 70,50 dan dikategorikan sangat layak sedangkan rerata skor untuk pendidik adalah 86 dikategorikan sangat layak (Tabel 6). Penelitian yang dilakukan oleh Situmorang dkk., (2015) tentang penerapan model pembelajaran problem based learning untuk meningkatkan hasil belajar siswa pada materi sistem ekskresi manusia. Proses pembelajaran yang ditawarkan dengan nilai keyakan baik akan berdampak terhadap hasil belajar siswa (S \& Bare, 2019).

Berdasarkan hasil analisis data uji lapangan terbatas, uji lapangan lebih luas dan uji kelayakan dengan menggunakan skala Likert dapat disimpulkan bahwa media pembelajaran biologi berbasis android pada materi sistem ekskresi di kelas VIII SMP yang dikembangkan layak digunakan. Pernyataan ini didukung oleh penelitian 
Kuswanto (2019) tentang pengembangan media pembelajaran berbasis android pada mata pelajaran biologi kelas XI menyatakan bahwa berdasarkan hasil dari beberapa tahap uji coba yang dilakukan oleh ahli dan responden dapat disimpulkan bahwa media pembelajaran berbasis android ini layak diterapkan dalam pembelajaran biologi di kelas XI. Penelitian yang dilakukan oleh Deadara (2017) tentang pengembangan media pembelajaran sistem reproduksi manusia berbasis android untuk meningkatkan pemahaman konsep peserta didik. Hasil penelitian menunjukkan bahwa kualitas media berdasarkan review oleh dosen ahli materi dan media serta guru biologi termasuk kriteria "baik" dengan beberapa aspek yang harus diperbaiki. Tanggapan siswa dalam penggunaan media menunjukkan 92\% respon positif, dan analisis pretest-posttest (gain score) mencapai kriteria tinggi dengan nilai 0,7 .

Penelitian yang dilakukan oleh Suryaningsih dkk., (2020) tentang pengembangan media pembelajaran praktikum virtual berbasis android untuk meningkatkan berpikir kreatif siswa. Media yang dikembangkan berupa android dapat meningkatkan pemahaman peserta didik. Hal ini didukung oleh pendapat Sadiman, (2012) menyatakan bahwa media android dapat dimanfaatkan oleh peserta didik untuk mempelajari sesuatu dapat terjadi kapan saja dan dimana saja. Lubis dkk, (2015) menyatakan bahwa pembelajaran menggunakan media teknologi memberikan pengaruh yang cukup signifikan terhadap pembelajaran.Berdasarkan penilaian yang dilakukan oleh para ahli dan responden bahwa penelitian ini dapat dijadikan salah satu alternatif pembelajaran biologi khususnya dalm kegiatan praktikum, serta meningkatkan berpikir kreatif siswa. Penelitian yang dilakukan oleh Aprilia (2018) tentang pengembangan media komik pembelajaran berbasis android pada materi archaebacteria dan eubacteria. Kuswanto (2019) tentang pengembangan media pembelajaran berbasis android pada mata pelajaran biologi kelas XI menyatakan bahwa berdasarkan hasil dari beberapa tahap uji coba yang dilakukan oleh ahli dan responden dapat disimpulkan bahwa media pembelajaran berbasis android ini layak diterapkan dalam pembelajaran biologi di kelas XI. Persentase yang diberikan oleh para ahli, peserta didik dan pendidik dikatakan sangat layak sehingga media komik pembelajaran berbasis android dapat dipergunakan untuk media alternatif dalam proses pembelajaran di sekolah, serta dapat meningkatkan minat baca peserta didik pada materi archaebacteria dan eubacteria.

\section{Revisi Hasil Uji Lapangan Terbatas}

Setelah melakukan uji lapangan terbatas, peneliti memperbaiki atau merevisi produk berdasarkan masukan dan saran dari hasil uji coba produk tersebut (Tabel 7).

Tabel 7. Revisi Hasil Uji Lapangan Terbatas

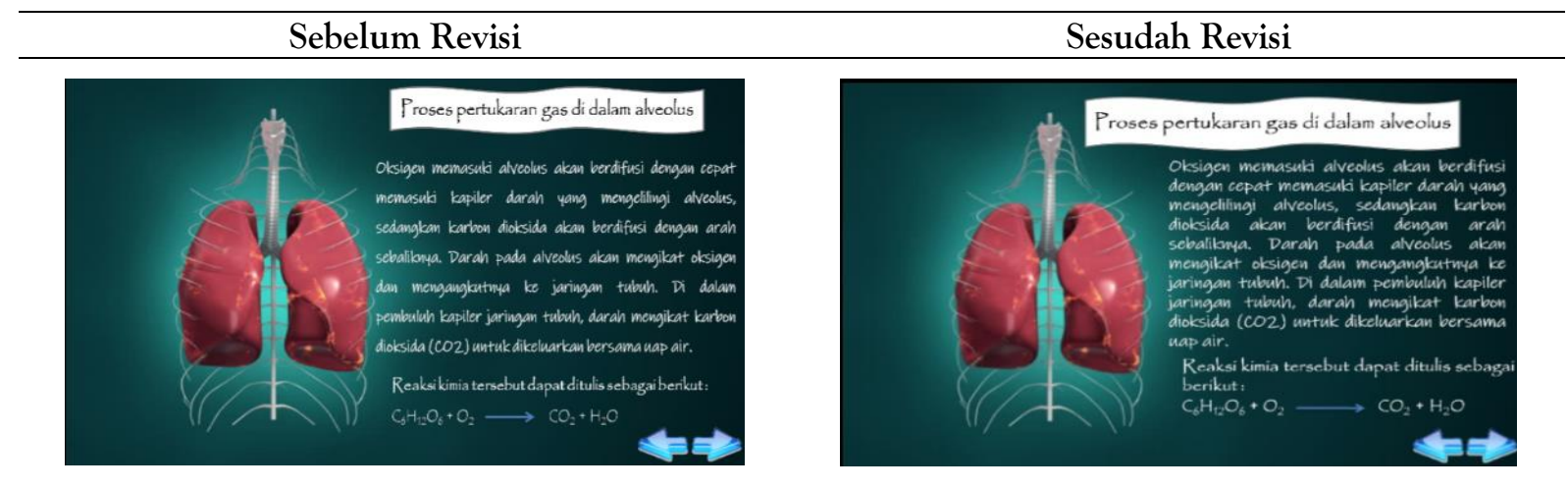

Uji Lapangan Lebih Luas

Produk media pembelajaran biologi berbasis android pada materi sistem ekskresi yang telah direvisi kemudian diuji kembali pada uji lapangan lebih luas. Uji lapangan lebih luas melibatkan peserta didik sebanyak 40 orang dan 2 orang pendidik mata pelajaran biologi. Saran dan tanggapan dari peserta didik yakni untuk materi hati pada bagian fungsi hati dan penjelasannya background dan tombol ke halaman sebelum dan halaman berikut warnanya sama. Tampilan media menjadi salah satu bagian penting dalam meningkatkan pemahaman peserta didik (Bare et al., 2021; Ndia et al., 2021).

\section{Revisi Hasil Uji Lapangan Lebih Luas}

Saran dan masukan dari uji lapangan lebih luas sebagai masukan untuk merevisi produk yang bertujuan menyempurnakan produk yang akan digunakan pada uji kelayakan (Tabel 8). 
Tabel 8. Revisi Hasil Uji Lapangan Lebih Luas

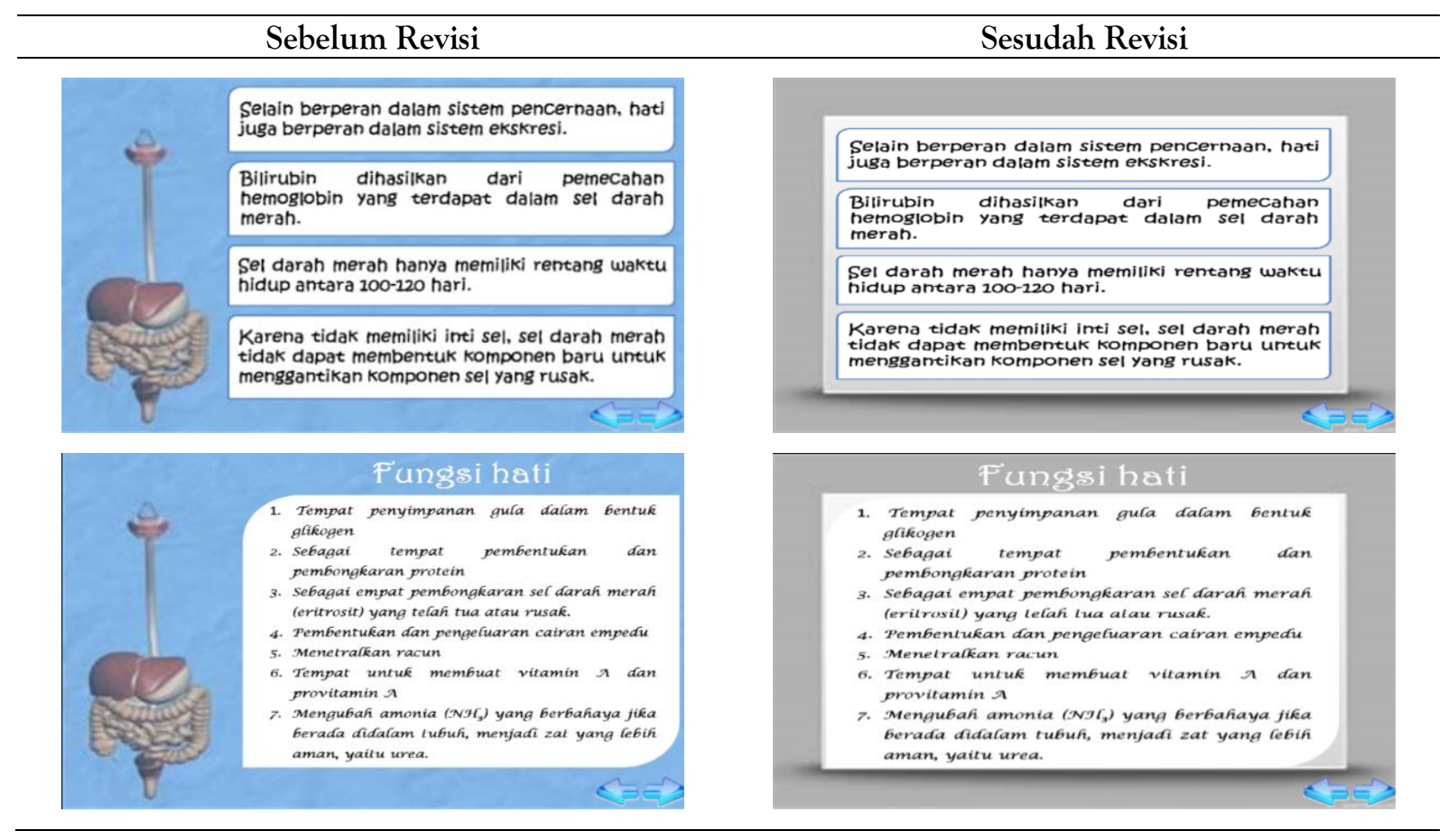

\section{Simpulan}

Berdasarkan analisis hasil pengolahan data penelitian yang dilakukan dan pembahasan diperoleh kesimpulan bahwa Media pembelajaran biologi berbasis android pada materi sistem ekskresi kelas VIII SMP dinyatakan valid dan layak di kelas VIII SMP.

\section{Daftar Pustaka}

Adi, C. H. (2016). Pengembangan Film Animasi Sub-Tema Pengertian Dan Jenis Lembaga Sosial Untuk Mata Pelajaran IPS SMP Kelas VII. Universitas Negeri Yogyakarta.

Aprilia, R. D. (2018). Pengembangan Media Komik Pembelajaran Berbasis Android Pada Materi Archaebacteria dan Eubacteria.

Bare, Y., Putra, S. H. J., Bunga, Y. N., Mago, O. Y. T., S, M., \& Boli, Y. T. (202I). Implementasi Biology Club I di SMA Karitas Watuneso, Kecamatan Lio Timur, Kabupaten Ende. Jurnal ABDINUS: Jurnal Pengabdian Nusantara, 4(2), 32I-328. https://doi.org/I0.29407/ja.v4i2.I5286

Bare, Y., \& Sari, D. R. T. (202I). Pengembangan Lembar Kerja Mahasiswa (LKM) Berbasis Inkuiri Pada Materi Interaksi Molekuler. BioEdUIN, II(I), 8. https://doi.org/I0.I5575/bioeduin.vI IiI.I2077

Borg, W. R., \& Gall, M. D. (2003). Educational Research: An Introduction. London : Longman Inc.

Chairunnisa, C. (2019). Pengembangan Mobile Learning Berbasis Android Pada Konsep Sistem Sirkulasi. Universitas Islam Negeri Syarif Hidayatullah.

Deadara, E. (2017). Pengembangan Media Pembelajaran Sistem Reproduksi Manusia Berbasis Android Untuk Meningkatkan Pemahaman Konsep Peserta Didik. Jurnal Prodi Pendidikan Biologi, 6, I3.

Dewi, N. K., \& Utami, N. R. (2016). Pengaruh Model Problem Based Learning Terhadap Kemampuan Berpikir Kritis Siswa Materi Sistem Ekskresi. Journal of Biology Education, 9.

Jano, F. (2019). Pengembangan Media Pembelajaran Kimia Berbasis Android Pada Materi Asam Basa Kelas XI SMA. Universitas Nusa Nipa.

Kuswanto, J. (2019). Pengembangan Media Pembelajaran Berbasis Android Pada Mata Pelajaran Biologi Kelas XI. Indonesian Journal of Business Intelligence (IJUBI), 2(2), 65. https://doi.org/I0.21927/ijubi.v2i2.I I39 
Ndia, F. X., Mago, O. Y. T., \& Bare, Y. (202I). Pengembangan Lembar Kerja Peserta Didik (LKPD) Koopertif Tipe Jigsaw Materi Klasifikasi Makhluk Hidup Kelas VII SMP. Quagga: Jurnal Pendidikan Dan Biologi, I3(2), 24-30. https://doi.org/I0.25I34/quagga.vI3i2.40II

Nuroifah, N., \& Bachri, B. S. (2015). Pengembangan Media Pembelajaran Berbasis Aplikasi Android Materi Sistem Ekskresi Siswa Kelas XI SMA NEGERI I Dawarblandong Mojokerto. Jurnal Mahasiswa Teknologi Pendidikan, 6(I), IO.

Permatasari, R. R. N., \& Wakhyudin, H. (2017). Pengembangan Media Misugi Anaya Pada Pembelajaran IPA Materi Sumber Energi Dan Kegunaannya. Prosiding Seminar Nasional Hima dan Prodi PGSD 2017, 10.

S, M., \& Bare, Y. (2019). Meningkatkan Hasil Belajar Siswa pada Konsep Perubahan dan Pelestarian Lingkungan Hidup dengan Model Discovery Learning di SMAS Katolik ST Gabriel Maumere. BIOEDUSCIENCE: Jurnal Pendidikan Biologi dan Sains, 3(2), 84-89. https://doi.org/I0.29405/j.bes/3284-893298

Setyantoko, M. (2016). Pengembangan Media Pembelajaran Mobile Learning Berbasis Android Dalam Pembelajaran Atletik Untuk Siswa SMP KELAS VII. Universitas Negeri Yogyakarta.

Simorangkir, A., \& Napitupulu, M. A. (2020). Analisis Kesulitan Belajar Siswa Pada Materi Sistem Ekskresi Manusia. Jurnal Pelita Pendidikan, 8(I). https://doi.org/I0.24II4/jpp.v8iI.I I247

Situmorang, R. M., Muhibbuddin, \& Khairil. (2015). Penerapan Model Pembelajaran Problem Basic Learning Untuk Meningkatkan Belajar Siswa Pada Materi Sistem Ekskresi Manusia. Jurnal Edubio Tropika, 3(2), 4.

Sizi, Y., Bare, Y., \& Galis, R. (202I). Pengaruh Model Pembelajaran Kooperatif Tipe Talking Stick Terhadap Keaktifan dan Hasil Belajar Kognitif Peserta Didik SMP Kelas VIII. Spizaetus: Jurnal Biologi dan Pendidikan Biologi, 2( I), 8.

Suryaningsih, Y., Gaffar, A. A., \& Sugandi, M. K. (2020). Pengembangan Media Pembelajaran Praktikum Virtual Berbasis Android Untuk Meningkatkan Berpikir Kreatif Siswa. Bio Educatio: (The Journal of Science and Biology Education), 5(I). https://doi.org/I0.31949/be.v5iI.2243

Ule, K. N., Bunga, Y. N., \& Bare, Y. (202I). Pengembangan Modul Pembelajaran Biologi Berbasis Jelajah Alam Sekitar (JAS) Materi Ekosistem Taman Nasional Kelimutu (TNK) SMA Kelas X. Diklabio: Jurnal Pendidikan dan Pembelajaran Biologi, 5(2), I0. https://doi.org/I0.33369/diklabio.5.2.I47-I56 